O'Donohue, W. \& Nelson, L. 2007 Let's be professional about this: Ideology and the psychological contracts of registered nurses. Journal of Nursing Management, 15 (5): 547-555.

\section{Let's be professional about this: ideology and the psychological contracts of registered nurses}

Wayne O’Donohue, ${ }_{2} \mathrm{BA}, \mathrm{MSc}, \mathrm{PhD}$ and Lindsay Nelson, BA, MSc, PhD School of Management, University of Tasmania, Hobart, Australia

Aims: This study explores whether there is evidence of an ideological component in the psychological contracts of professional employees, as well as evidence of credible supporting commitments by their employer.

| Background: Fundamental changes in the employment context have prompted many individuals to seek a closer alignment between themselves and their work, as well as with the organizational and broader societal contexts. For many professional employees identification with their professional ideology is a significant factor in producing such an alignment.

| Method: The study uses an exploratory qualitative approach to analyse interview data collected from a sample of registered nurses employed in an Australian public hospital.

| Results: The analysis identifies psychological contract terms best understood by reference to an ideological currency. It also suggests that the organization is perceived as obligated to provide credible support for that professional contribution, and the perceived lack of such support has significant impacts.

| Conclusions: The findings raise doubts about the utility of the concept of a psychological contract that recognises only economic and socio-emotional exchanges for understanding the psychological contracts of professional employees.

$$
\text { . }
$$

\section{INTRODUCTION}

In Australia, the pursuit of increased organizational responsiveness, productivity, flexibility and innovation has occurred in both private and public sector organizations. As a consequence, changes have occurred in employment arrangements that have led to a destabilising of the relationship between employee and employer (Kabanoff, et al. 2000). Prior to these changes occurring, the employment relationship was constructed around an individual's loyalty and commitment to, and trust in, the employing organization. In return, the employer provided job security, career prospects, and training and development opportunities. Today, however, the individual is required to accept longer hours, more responsibility, multi-skilling and role ambiguity. In return, the organization provides higher pay, rewards for performance and a job rather than a career (Millward \& Brewerton 2000).

Research suggests these changes have prompted many individuals to seek a closer alignment between themselves and their work, as well as with their organizational and broader societal contexts (Ashmos \& Duchon 2000; Burr \& Thomson 2002). Thompson and Bunderson (2003) suggest there is evidence that it is not just individuals seeking this closer alignment. Organizations are seeking to establish a broader explicit 'connection' with their environments through the adoption of cause-driven missions in an endeavour to induce greater employee contributions. These perceived trends have implications particularly for those individuals for whom meaning and purpose in work is achieved in part through identification with their profession and its ideology about work and organizations. This paper explores the perceptions of professional employees with regard to the link between their professional ideologies and their psychological contracts, a construct which is widely used to interpret and understand the dynamics of the employee-organization relationship.
Formatted: Justified, Automatically adjust right indent when grid is defined, Adjust space between Latin and Asian text, Adjust space between Asian text and numbers

Formatted: Font: Not Italic, No underline, Font color: Auto, Complex Script Font: Not Italic

\section{Field Code Changed}

Formatted: Font: Bold, Italic, Complex Script Font: Bold, Italic

Formatted: Font: (Default) Times New Roman, (Asian)

Times New Roman, 14 pt, Bold,

Complex Script Font: Times

New Roman, 14 pt, Bold,

(Complex) Arabic (Saudi

Arabia), English (Australia)

Formatted: Font: (Default)

Times New Roman, (Asian)

Times New Roman, 12 pt,

Complex Script Font: Times

New Roman, 12 pt, (Complex)

Arabic (Saudi Arabia), English (Australia)

Formatted: Font: (Default) Times New Roman, (Asian) Times New Roman, 12 pt, Complex Script Font: Times New Roman, 12 pt, (Complex) Arabic (Saudi Arabia), English (Australia)

Formatted: Font: (Default) Times New Roman, (Asian) Times New Roman, 12 pt, Complex Script Font: Times New Roman, 12 pt, (Complex) Arabic (Saudi Arabia), English (Australia)

Formatted: Font: (Default) Times New Roman, (Asian) Times New Roman, 12 pt, Complex Script Font: Times New Roman, 12 pt, (Complex) Arabic (Saudi Arabia), English (Australia)

Formatted: J ustified, Line spacing: single

Deleted: _ _ Page Break 


\section{THE PSYCHOLOGICAL CONTRACT}

The majority of psychological contract research to date (Coyle-Shapiro et al. 2004) uses a cognitive-perceptual approach that defines the psychological contract concept as the individual's beliefs in mutual obligations entered into with the employer (either the organization or another person). These beliefs are predicated on the perception that promises have been made, and considerations offered in exchange, which bind the employee and the organization to a set of reciprocal obligations (Rousseau \& Tijoriwala 1998).

Within the psychological contract literature, this definitional stance is mostly operationalised using an interpretative framework originally developed by Rousseau (1995). In accord with the notions of economic/transactional and socio-emotional/relational exchange found in social exchange theory (Blau 1964) and relational contract theory (Macneil 1985), Rousseau's (1995) interpretative framework links content character directly to generic contract features to describe four contract types. Firstly, the transactional type is short-term in focus with explicit performance terms. Secondly, there is the relational type that has longterm commitments by both parties, and non-explicit performance terms. Thirdly, the balanced (hybrid) type has uniquely complex combinations of transactional and relational terms, and aims at a long-term relationship while at the same time specifying performance requirements. The balanced type is becoming increasingly commonplace in contemporary organizations (Millward \& Brewerton 2000). The fourth type is the transitional contract that offers no guarantees because of instability in the organization's environment and conditions (Rousseau, 1995).

| The transactional and relational contract types are the foundation classifications in this contract typology. The currency of transactional exchange is reasonably explicit, short-term and economic or monetisable in nature; such exchange assumes rational and self-interested parties, and does not result in ongoing interdependence. Relational exchange is more complex and promotes interdependence through a commitment to the collective interest over selfinterest; its currency is socio-emotional in nature and therefore less clear. It evolves over time, and involves long-term investments from which withdrawal is difficult (Rousseau \& McLean Parks 1993).

By linking currency to the way in which individuals respond in the event of contract breach by the organization (see Herriot \& Pemberton 1996; Morrison \& Robinson 1997; Turnley \& Feldman 2000), the transactional/relational interpretative framework has contributed significantly to our understanding of how and why individuals respond to change in the employment relationship (Anderson \& Schalk 1998). Notwithstanding this success, the reliability and adequacy of the framework has long been an issue of debate (see Arnold 1996; Guest 1998a, 1998b; Coyle-Shapiro et al. 2004), and remains so today. One emerging area of debate that has significant conceptual implications for the psychological contract concerns the possibility that the accepted definition of contract terms as being economic or socioemotional in nature may be inadequate for understanding the psychological contracts of employees who conceptualise work and their relationship to the organization from an ideological perspective (Burr \& Thomson 2002; Thompson \& Bunderson 2003).

Drawing on social exchange theory (Blau 1964) that make clear that both material and non-material contributions may play a role in the employee-organization relationship, Thompson and Bunderson (2003) propose an expansion of the interpretative framework to incorporate the notion of an 'ideology-infused' psychological contract. Such a contract would include a combination of three forms of currency - economic, socio-emotional and ideological - the distinctions between which are shown in Table 1 below. Thompson and Bunderson (2003) suggest that when the individual perceives ideological commitments as part of the currency exchange, then there will be an accompanying perception that the organization will provide a supportive environment in return. 
Within the expanded framework of the ideology-infused contract, Thompson and Bunderson (2003: 574) define ideological currency broadly as 'credible commitments to pursue a valued cause or principle (not limited to self-interest) that are implicitly exchanged at the nexus of the individual/organization relationship'. Under this broad definition, such causes might include for instance, occupational ideals such as professional competence, or social ideals such as the right of every member of the community to access high quality health services regardless of their individual socio-economic status. Thus, by broadening the range of contract terms the psychological contract can contain, the concept of an ideologyinfused contract provides a means for exploring the link between professional ideologies and the psychological contract for professional employees.

Table 1: Psychological contract currencies

\begin{tabular}{|c|c|c|c|}
\hline & Economic currency & Socio-emotional currency & Ideological currency \\
\hline Organization's & Provide $\quad$ continued & Provide training, career & Demonstrate $\quad$ credible \\
\hline obligations & $\begin{array}{lr}\text { employment, safe } & \text { working } \\
\text { environment, } & \text { fair } \\
\text { compensation } & \\
\end{array}$ & $\begin{array}{l}\text { development, promotion } \\
\text { opportunities, long-term job } \\
\text { security }\end{array}$ & $\begin{array}{l}\text { commitment to a valued } \\
\underline{\text { social cause }}\end{array}$ \\
\hline Individual's & Fulfil formally specified role & Fulfil generalised role & $\underline{\text { Participate }}$ \\
\hline$\underline{\text { obligations }}$ & $\underline{\text { requirements }}$ & $\begin{array}{l}\text { obligations; } \quad \text { organizational } \\
\text { commitment } \\
\text { involvement; OCB }\end{array}$ & $\begin{array}{l}\text { organization's mission/cause } \\
\text { organizational and societa } \\
\text { citizenship behaviour }\end{array}$ \\
\hline$\frac{\text { Salient }}{\text { beneficiary }}$ & $\underline{\text { Self }}$ & $\begin{array}{l}\text { Self and organizational } \\
\underline{\text { community }}\end{array}$ & $\begin{array}{l}\text { Society, some segment } \\
\text { thereof, or an intangible } \\
\text { principle }\end{array}$ \\
\hline Affiliation & 'The organization gives me a & 'The organization nurtures & 'The organization shares my \\
\hline$\underline{\underline{\operatorname{logic}}}$ & $\begin{array}{l}\text { fair day's pay for a fair day's } \\
\text { work.' }\end{array}$ & $\begin{array}{l}\text { my professional development } \\
\text { and sense of community.' }\end{array}$ & $\begin{array}{l}\text { passion, cause, and/or } \\
\text { mission.' }\end{array}$ \\
\hline $\begin{array}{l}\text { Model of } \\
\text { human nature }\end{array}$ & Egoistic, instrumental & Collectivistic, socialised & Principled, involved \\
\hline
\end{tabular}

\section{PROFESSIONAL IDEOLOGIES}

While professions derive their identity from the distinctive nature of the specialised knowledge and skills their members are required to have, it is possible to identify from the literature (Greenwood 1966; Abbott 1988; Trice 1993; Wallace 1995) certain general attributes that professions are likely to exhibit and which professional ideologies reflect.

The first of these attributes is possession of a systematic and abstract body of specialised knowledge expressed in a language known fully only to the members of the profession. Second, the members of the profession claim autonomy in the application of their specific knowledge and resist interference in their work by those who are less qualified. Third, professions maintain bodies that are heavily involved in the profession's management, including setting minimum qualification standards for entry that in some cases may also be state-legislated requirements for approval to practice. Fourth, membership of a profession is likely to entail a commitment to a code of ethics or practice that places community interests and those of the profession above self-interest. Fifth, because of their monopoly of professional expertise, members of professions claim authority over, but share responsibility with, clients who are assumed to be lesser skilled and so unable to determine their own needs or properly judge the quality of service provided by members of the profession. Together, these attributes are referenced in the distinctive, complex ideologies that professions develop and sustain. In particular, the attributes of professional competence, a client focus with its
Formatted: Font: Bold Complex Script Font: Bold

Formatted: Font: Times, Bold, Complex Script Font: Bold

Formatted: Body Text 3, Centered, Indent: First line:

$0.63 \mathrm{~cm}$, Space After: $6 \mathrm{pt}$

Formatted: Font: I talic Complex Script Font: I talic

Formatted: J ustified, Indent:

First line: $0 \mathrm{~cm}$, Line spacing: single

Formatted: J ustified, Line spacing: single 
concomitant responsibility to adhere to a code of ethical principles, and a service and otherorientation, all carry significant weight (Greenwood 1966; Abbott 1988; Trice 1993; Wallace 1995).

| These values and beliefs form an important part of the mental schema on which a professional's perspective of the organization and their relationship to it is based, and which differs markedly from the perspective with which management views that relationship. This divergence of perspective results from the different underlying principles on which professional and management schemas for conceptualising the organization are based. Bunderson et al. (2000) models four generic ideological schemas: the bureaucratic and market enterprise schemas that reflect generic management values and beliefs; and the professional group and community service schemas that reflect generic professional values and beliefs. In essence, the two management schemas are based on the administrative principle, which emphasises authority based on incumbency of a legally defined office, commitment to the organization, hierarchical decision-making, and efficiency (Trice 1993). In contrast, the two professional schemas are based on the occupational principle, which emphasises authority based on professional competence, commitment to the work, collegial decision-making, and service (Trice 1993). The management schemas conceptualise the organization as a system organized and managed to achieve common goals in an efficient, integrated and co-ordinated way. The professional schemas comprehend the organization as a system focussed on professional goals and objectives that reflect professional competence and excellence, high quality outcomes, a commitment to service, and contribution to the benefit of the community and public good. These generic schemas (Bunderson et al. 2000) are useful in that they clarify the ideological differences between the professional and management perspective, and show how such differences between professionals and management can produce alternative views on the individual's relationship to the organization and the psychological contract.

It is against this background that this paper explores whether there is evidence of an ideological component in the psychological contracts of professional employees, as well as evidence of perceptions that the employing organization should provide credible commitments in support of that component.

\section{RESEARCH METHODOLOGY}

The findings reported here form part of a broader exploratory and qualitative study that examined the perceptions of nursing, scientific research, and teaching professionals with regard to the link between their professional ideologies and their psychological contracts. (O'Donohue, Sheehan, Hecker \& Holland in press)

The nursing sample comprised 10 nursing professionals employed in an Australian public hospital in a metropolitan area where it is the sole public-sector provider of a broad range of medical and nursing services. Nursing professional was defined as a registered nurse, that is a nurse registered with the government regulatory authority as having the necessary qualifications and competence to practice professionally. A single public hospital in one region was selected to circumvent the need to consider the possibility of organizational variation and differences between industrial and professional regulatory mechanisms across Australian states as explanatory variables. Nursing was selected as the focus profession not for generic or instrumental reasons but rather because it was considered an intrinsically interesting subject in its own right. Also, as a profession, nursing clearly exhibits those attributes by which professions are defined, such as a specialised field of professional 
knowledge, highly organized industrial and professional associations, regulated professional registration requirements, and extensive and formal codes of practice and ethics.

| As this is exploratory qualitative research, semi-structured interviews were selected as the best means of data collection, because they would allow appropriate exploration of the complex issues under investigation and produce a rich data set of comments for analysis (Neuman 2000; Babbie 1992). Each interview took the form of conversation centred on:

- the interviewee's values and beliefs about what being a professional meant;

- the professional dimension of his/her psychological contract and related obligations the organisation was perceived to have; and

- the match between the professional dimension of the interviewee's psychological contract and actions taken by the employer to meet related obligations.

Each interview was conducted in accordance with procedures approved by the university ethics committee. These procedures were designed to ensure informed consent and protection of the confidentiality and privacy of interviewees. The researcher tape-recorded each interview, with each being subsequently transcribed. In order to ensure that an interviewees views were clearly and accurately recorded, interviewees were then provided with a copy of their interview transcript and invited to review and confirm or alter their words if they so wished. Those confirmed transcriptions formed the primary data set for analysis.

| At the commencement of each interview, each participant was asked to complete two questionnaires as a prelude to discussion. The purpose of administering the questionnaires was not to conduct a group psychometric analysis (the number of participants was too small), but to set the scene for the subsequent interview discussion. The two instruments used were the 17 item shortened version of the Psychological Contract Scale (Millward \& Hopkins 1998), and the 12 item instrument developed by Bunderson et al. (2000) for measuring organizing models.

| The two sets of questionnaire data were analyzed using simple descriptive statistical techniques. Because of the small sample size and limited aim behind the use of the questionnaires, sophisticated statistical techniques commonly used in the analysis of psychometric data were not considered appropriate. Interview data were analyzed manually and with the assistance of the computer software application known as Nonnumerical Unstructured Data Indexing Searching and Theorising (NUD*IST). A treestructured indexing system was developed initially using a number of broad categories or nodes to classify and organise the interview data, followed by the development of codes within each node to allow more specific categorisation and organisation of the content of each interview. These codes were derived from the interview material and the literatures concerned with the psychological contract and the development of professions.

To bolster the trustworthiness of the data analysis, the choice of analytical methods, and more generally the development of the research methodology, were guided by four measures of quality - confirmability, dependability, credibility, and transferability articulated for use in the case of research using qualitative method (Lincoln \& Guba 1985; Miles \& Huberman 1994). For example, the combination of qualitative and quantitative methods was chosen for its flexibility and congruence with the exploratory emphasis in the research questions. These questions in turn served as anchor points and as guides for all researcher activity over the duration of the study. Similarly, the requirement to abide by protocols pre-approved by the university ethics committee, covering data collection and the 
handling of participant contributions, also assisted in ensuring consistency of method and procedure over the duration of the study.

\section{RESULTS AND DISCUSSION \\ General}

Responses to the Psychological Contract Scale (Millward \& Hopkins 1998) indicated that, in terms of the transactional/relational interpretive framework, all interviewees perceived their psychological contract as comprising both relational and transactional components, with a predominant orientation towards relational over transactional. All interviewees indicated that they expected to grow professionally within the organization, but the majority did not see themselves as likely to remain with the organization for the long term.

| In assessing the hospital's current performance level (Bunderson et al. 2000), all interviewees indicated an assessment reflective of a cognitive framework and conceptualisation of the organization consistent with a professional work ideology. For example, there was a unanimous view that the hospital should be characterised to the greatest extent by professionally competent medical staff, clinical excellence, and high quality health care. A concern with the health of the community, community access to health care, and a general community orientation were considered by all the interviewees as only marginally less important attributes for the hospital to have.

\section{Ideological currency}

On the matter of whether there is evidence for an ideological currency distinct from the transactional and relational currencies, the quotes below are indicative of views that were expressed by interviewees during discussion. In general, interviewees perceived the core components of nursing's professional ideology - professional expertise and excellence, client focus, and an other-orientation or sense of contribution outside the individual to the broader public good - as important and identifiable employee contributions.

| - 'I've got ... a more modern view of a nurse and so I look at them as being a clinical specialist in an area ... [and] as having a minimum of a bachelor's degree and then perhaps postgraduate qualifications after that. I look at them as being people who are active in the health care system who have reasonable human values, accepting of people from all walks of life, cultures, race, age, anything like that, and that they're competent clinicians.' Interviewee A5

| - 'I've been nursing for a long time. I just feel that ... you're there to help provide high quality care for the patients to the best of your ability within the resources provided to you by the community. I've always believed in excellence in nursing and professional development and it's for the benefit of the patient really.' Interviewee A7

\section{Credible commitment}

According to Thompson and Bunderson (2003), if part of the individual's contribution is made in the form of ideological currency then the individual will perceive the organization to be obligated to provide credible commitments as part of the employment exchange. The quotes below are indicative of views that were expressed by interviewees. In general, notwithstanding the individual's ideology-related contribution, the hospital was perceived by interviewees as not making matching or supportive credible commitments. 
- '[T]here have also been changes in the management structure. ... We now have 3 people, 1 for each of the clinical services, and ... there's an increased business side to these 3 figureheads. ... When we had one figurehead, that person I think had more of a role in promoting professional collegiality and initiatives. ... I think we now lack a professional focus in our nursing leadership in this hospital.' Interviewee A9

- ' '[T]hey treat nurses as a commodity. ... Now it's not inconceivable that I can be asked to go to from my speciality to a psychiatry ward. ... I can't name another profession that would make the people do that. Do they grab trial lawyers out of court to do some will work or conveyancing? It just doesn't happen. It comes down to a numbers thing ... so nurses are treated like absolute commodities.' Interviewee A6

- 'One of the important things about a nurse is that you've got to be able to go home after an 8 or 10-hour shift, and feel like you've done everything that you can possibly can. ... You don't want to go off ... [having] ... been abused by relatives and patients because the organization has let you down. That happens quite a lot.' Interviewee A4

- 'I know wards in the hospital that hold raffles just so that they can get the money to buy blood pressure machines. ... They've [management] opened up some of the medical wards, but they've closed other medical wards and made them into offices. ... We've got less beds within the main structure of the hospital than we had. How can they say that we've got the beds and the structure to incorporate our community when we take patients from all over the State?' Interviewee A4

- 'I have been approached by outside organizations to do education sessions. ... The organization wasn't quite willing to give me a definite answer; ... it seemed easier to do it for my professional organization than it did for my actual employer. ... It's almost always asked would you be doing it on your own time.' Interviewee A3

\section{Importance of ideological currency and credible commitment}

Consistent with social exchange theory, psychological contract research (Rousseau 1995; Morrison \& Robinson 1997) suggests that where the individual perceives the organization as failing to fulfil its obligations under the psychological contract then the individual may alter their behaviour and attitudes towards the organization. The quotes below are indicative of views that were expressed by interviewees during discussion. In general, comments made by interviewees suggested that the hospital's lack of support for the professional contribution of nurses was reflected in a decreased focus by the individual on the organization and a concomitant increase in focus on the profession. Interviewees described a lack of congruence between the type of employment relationship that each individual desired and that which management were perceived as offering, that is that the hospital has work to do and anyone with the right skills can do it. All interviewees appeared to want a relationship with the organization in which they were cared about, treated with respect, and in which their professional contribution was supported by the hospital.

| - 'I don't have any loyalty to the organization at all. I have a loyalty to the people that I work with, my peers and the patients that I care for.' Interviewee A4

| - 'Just terribly disillusioned, really, certainly with the hospital as an organization. To the point where because my contract finishes in January next year, I'm really thinking quite hard about what I can do with my level of experience to work outside this hospital. I find it incredibly frustrating. ... [It] is really disappointing.' Interviewee A10

| - 'I certainly think that the predominant vibe is mostly a negative. It's not an inspirational place to work. ... I [want] ... an organization that has an air of confidence, an air of 
positiveness, where employees feel valued and therefore have more job satisfaction. Things like professional development and flexibility in employment instead of having these contracts with no guarantee, recognising that people need some sort of ... security, and just listening to employees and involving people at all levels in making changes.' Interviewee A8

\section{Impact of perceived breach}

In considering the possibility that ideological currency can form part of the employment exchange for some employees, Thompson and Bunderson (2003) also formulated propositions relating to how individuals might interpret organizational intent and actions with regard to the non-delivery of credible commitments on ideological obligations forming part of the psychological contract. The data collected in this study are relevant to several of these propositions.

Firstly, Thompson and Bunderson (2003) propose that perceived breaches of ideologyinfused contracts would be seen as the result of intentional reneging on the part of the organizational decision-makers. They also suggested goal displacement, that is to say a shift in emphasis from core ideals to an emphasis on the means intended to achieve ideological objectives as ends-in-themselves, would be perceived by ideologically committed employees as lying behind the organization's failure to deliver on its obligations. Several interviewees expressed strong feelings, concerning the hospital's lack of support for core elements in the nursing's professional ideology, that support these propositions.

| - 'You know I think the management are under pressure with their hierarchy to come in with a certain budget. ... Sometimes decisions are made that are economical rather than professional.' Interviewee A1

- 'CEOs ... a 3 year contract or a 2 year contract, ... come in, ... perform well or do what they think is well in something, and then they go again and they leave a mess generally. ... [T] hey leave behind a very tight organization that is decreased in its capacity to care for the community as a whole. That's what they've left behind. ... I don't think that management have got the bigger picture at all. I think that they've got a very tunnelled view of what they've done. ... I suppose the hospital would be very, very, very well run for management if it didn't have any patients.' Interviewee A4

| - 'It's always about saving money or increasing productivity with the resources you've got. ... I think some of the people who are involved in the management ... have by definition lost sight of what nursing is about. ... They're managing nursing budgets but they don't nurse per se any more.' Interviewee A6

Secondly, Thompson and Bunderson (2003) propose that the relationship between perceived breach and violation will be weaker for ideological obligations than for transactional and/or relational obligations. They argue that even when employees are deeply committed to fulfilment of ideological objectives, they will at the same time be tolerant of the organization's failure to manifest a credible commitment to those objectives. Employee attributions of breach to the political, social, or economic context in which the organization operates will also attenuate the likelihood that a perceived ideological breach will result in violation. Thompson and Bunderson (2003) also contend that employees who have an ideology-infused psychological contract will tolerate some level of non-delivery by the organization because they recognise the organization needs to avoid alienating important stakeholders and constituents. Comments by two interviewees were reflective of the majority of comments related to these propositions. 
- 'I think it definitely still inspires me to continue fighting for my patients as they are the heart of what I want to improve. I guess the frustration continues though in that the next time you talk to your manager, or write an incident report, you start to get that "oh well where's this going to go", but I guess then I turn it around and I still encourage other people to do it because I think, well power in the numbers'. Interviewee A3

- 'I think ... even though the end goal I think is the same for both me and the organization, the way of getting there is done very differently. ... They want to pump them through because of the political pressures, ... [and] the social pressures. I ... do it just for the social pressures and that is my job. So we both want the same thing ... although sometimes I feel, like many people, that we may be going in opposite directions even though I know in my own mind that it's not that way' Interviewee A6

- 'Being demoralised does you no good so you then start to act again and agitate again to get some cash. Now you may get demoralised 5 or 6 or 20 or 30 times in that time but I think because the process goes on, the patients still get operated on, everything moves forward and you still need that equipment, you can sort of develop some fight again, even though you're banging your head against the wall sometimes.' Interviewee A6

\section{CONCLUSION}

The analysis focussed on the perceptions of professional employees with regard to the link between their professional ideologies and their psychological contracts. Responses to the PCS (Millward \& Hopkins 1998) indicated that the sample of registered nurses held a predominantly relational perspective on their psychological contract. However, this finding must be understood in the light of the fact that the PCS (Millward \& Hopkins 1998) recognises only two forms of exchange currency - economic/transactional and socioemotional/relational. The data gathered using the Bunderson et al. (2000) questionnaire and at interview indicated that all interviewees had a strong professional affiliation. Analysis of these data, particularly interview comments made by the sample of registered nurses, has identified perceptions of the psychological contract that are best understood by reference to an ideological currency. The analysis also suggests that the study participants perceived the organization to be obligated to demonstrate a credible commitment and support for their professional contribution of professional competence, a primary focus on the patient, and a service orientation. The failure of the organization to deliver on its perceived obligation in this regard clearly was a significant factor in the participating nurses' perceptions of their psychological contract and their relationship to the organization.

| In considering the transferability of these findings several aspects of the study's research methodology need to be taken into account. First, as a consequence of the convenience sampling technique used in the study the sample of registered nurses was neither representative of registered nurses in the subject organization or of the nursing profession generally. Second, the small sample size and primarily qualitative nature of the data meant the analysis could not be meaningfully controlled for a range of demographic variables that previous psychological contract research has shown may attenuate reactions to psychological contract breach and fulfilment. Third, the research setting selected for this exploratory study was limited to one public hospital. Consequently, the principle of public service to the community, which historically has underpinned and shaped public sector organizational goals and objectives, may have led to the sampled nurses being more sensitive to ideological breaches than nurses working in other non-public hospital settings. Also, in regard to the specific hospital setting chosen for the study, major funding crises and their impacts,
Formatted: Justified, Line spacing: single, No bullets or numbering

Formatted: Justified, Line spacing: single 
particularly on staffing, that it has experienced in recent years are likely to have shaped the perceptions of the sampled nurses significantly. Hence, using a broader sample of hospital settings, embracing the private sector and not-for-profit organizations, might also shed light on the transferability of this study's findings.

In conclusion, this paper has presented evidence of an ideological component in the psychological contracts of professional employees, as well as evidence of perceptions that the employing organization should provide credible commitments in support of that component. This evidence raises doubts about the utility of the concept of a psychological contract underpinned solely by economic/transactional and socio-emotional/relational exchanges for describing and understanding the psychological contracts of professional employees. 


\section{REFERENCES}

| Abbott, A. (1988) The system of professions: an essay on the division of labour. University of Chicago Press, Chicago.

| Anderson, N. \& Schalk, R. (1998) The psychological contract in retrospect and prospect. Journal of Organizational Behaviour, 19 (S1), 637-647.

| Arnold, J. (1996) The psychological contract: a concept in need of closer scrutiny. European Journal of Work and Organizational Psychology, 5 (4), 511-520.

| Ashmos, D. P. \& Duchon, D. (2000) Spirituality at work: a conceptualisation and measure. Journal of Management Inquiry, 9 (2), 131-145.

Babbie, E. (1992) The Practice of Social Research. (6th edition). Wadsworth, California.

Blau, P.M. (1964) Exchange and power in social life. Wiley, New York.

Bunderson, J. S., Lofstrom, S. M. \& Van de Ven, A. H. (2000) Conceptualising and measuring professional and administrative models of organizing. Organizational Research Methods, 3 (4), 366-391.

| Burr, R. \& Thomson, P. (2002) Expanding the network: what about including 'the all' in the psychological contract. Paper presented at the Academy of Management Conference, Denver, USA.

| Coyle-Shapiro, J. A-M., Shore, L. M., Taylor, M. S., \& Tetrick, L. E. (Eds.) (2004) The employment relationship: examining psychological and contextual perspectives. Oxford University Press, New York.

Greenwood, E. (1966) The elements of professionalisation. In H. M. Vollmer \& D. L. Mills (Eds.) Professionalization: 9-19, Prentice-Hall, Englewood Cliffs.

Guest, D. E. (1998a) Is the psychological contract worth taking seriously? Journal of Organizational Behaviour, 19 (S1), 649-664.

| Guest, D. E. (1998b) On meaning, metaphor and the psychological contract: a response to Rousseau. Journal of Organizational Behaviour, 19 (S1), 673-677.

Herriot, P. \& Pemberton, C. (1996) Contracting careers. Human Relations, 49, 757-790.

Kabanoff, B., Jimmieson, N. L., \& Lewis M. J. (2000) Psychological contracts in Australia: a 'fair go' or a 'not-so-happy transition'? In D. M. Rousseau \& R. Schalk (Eds.) Psychological Contracts in Employment: Cross Cultural Perspectives: 29-47, Sage, Beverly Hills.

Lincoln, Y \& Guba, E. (1985) Naturalistic enquiry. London, Sage.

Macneil, I. R. (1985) Relational contract: what we do and do not know. Wisconsin Law Review, 483-525.

Millward, L. J. \& Brewerton, P.M. (2000) Psychological contracts: employee relations for the 21st century. In C. L. Cooper \& I. Robertson (Eds.), International Review of Industrial and Organizational Psychology, 15, 1-63, Wiley \& Sons, Chichester.

Millward, L. J. \& Hopkins, L. J. (1998) Psychological contracts, organizational and job commitment. Journal of Applied Social Psychology, 28 (16), 1530-1556.

Morrison, E. W. \& Robinson, S. L. (1997) When employees feel betrayed: A model of how psychological contract violation develops. Academy of Management Review, 22 (1), 226-256. 
| Neuman, W. (2000) Social Research Methods: Qualitative and Quantitative Approaches. Allyn and Bacon, Boston.

O'Donohue, W., Sheehan, C., Hecker, R. \& Holland, P. (2007) The psychological contract of knowledge workers. Journal of Knowledge Management, 11(2), In press.

| Rousseau, D. M. \& McLean Parks, J. M. (1993) The contracts of individuals and organizations. In L.L. Cummings and B. M. Staw (Eds) Research in Organizational Behavior, JAI Press, Greenwich.

| Rousseau, D. M. \& Tijoriwala, S. A. (1998) Assessing psychological contracts: issues, alternatives and measures. Journal of Organizational Behaviour, 19 (S1), 679-695.

| Rousseau, D. M. (1995) Psychological Contracts in Organizations: Understanding Written and Unwritten Agreement, Sage, Newbury Park.

| Thompson, J. A. \& Bunderson, J. S. (2003) Violations of principle: ideological currency in the psychological contract. Academy of Management Review, 28 (4), 571-587.

Trice, H. M. (1993) Occupational sub-cultures in the workplace, ILR Press, Ithaca NY.

Turnley, W. H., \& Feldman, D. C. (2000) Re-examining the effects of psychological contract violations: unmet expectations and job dissatisfaction as mediators. Journal of Organizational Behaviour, 21 (1), 25-42.

Wallace, J. E. (1995) Organizational and professional commitment in professional and nonprofessional organizations. Administrative Science Quarterly, 40 (2), 228-255. 


\begin{tabular}{ll} 
Page 10: [1] Deleted & Author \\
& Page Break \\
\hline
\end{tabular}

Table 1: Psychological contract currencies

\begin{tabular}{|c|c|c|c|}
\hline & Economic currency & Socio-emotional currency & Ideological currency \\
\hline $\begin{array}{l}\text { Organization's } \\
\text { obligations }\end{array}$ & $\begin{array}{lr}\text { Provide } & \text { continued } \\
\text { employment, safe } & \text { working } \\
\text { environment, } & \text { fair } \\
\text { compensation } & \end{array}$ & $\begin{array}{l}\text { Provide training, career } \\
\text { development, promotion } \\
\text { opportunities, long-term job } \\
\text { security }\end{array}$ & $\begin{array}{l}\text { Demonstrate } \\
\text { commitment to a } \begin{array}{r}\text { credible } \\
\text { social cause }\end{array}\end{array}$ \\
\hline $\begin{array}{l}\text { Individual's } \\
\text { obligations }\end{array}$ & $\begin{array}{l}\text { Fulfil formally specified role } \\
\text { requirements }\end{array}$ & $\begin{array}{lr}\text { Fulfil generalised role } \\
\text { obligations; } & \text { organizational } \\
\text { commitment } & \text { and } \\
\text { involvement; } & \text { OCB }\end{array}$ & $\begin{array}{l}\text { Participate in the } \\
\text { organization's mission/cause; } \\
\text { organizational and societal } \\
\text { citizenship behaviour }\end{array}$ \\
\hline $\begin{array}{l}\text { Salient } \\
\text { beneficiary }\end{array}$ & Self & organizational & $\begin{array}{l}\text { Society, some } \\
\text { thereof, or an intangible } \\
\text { principle }\end{array}$ \\
\hline $\begin{array}{l}\text { Affiliation } \\
\text { logic }\end{array}$ & $\begin{array}{l}\text { 'The organization gives me a } \\
\text { fair day's pay for a fair day’s } \\
\text { work.' }\end{array}$ & $\begin{array}{l}\text { 'The organization nurtures } \\
\text { my professional development } \\
\text { and sense of community.' }\end{array}$ & $\begin{array}{l}\text { 'The organization shares my } \\
\text { passion, cause, and/or } \\
\text { mission.' }\end{array}$ \\
\hline $\begin{array}{l}\text { Model of } \\
\text { human nature }\end{array}$ & Egoistic, instrumental & Collectivistic, socialised & Principled, involved \\
\hline
\end{tabular}

(Adapted from: Thompson \& Bunderson 2003: 575 - An expanded framework for understanding psychological contracts: a comparison of currencies) 